\title{
難溶性薬物グリセオフルビンの溶出試験と家鬼血中濃度測定
}

\author{
菅原和信, ${ }^{\mathrm{a})}$ 石川 修, 長岡英世, 板垣末広, 豊口禎子 \\ 山形大学医学部附属病院薬剈部*
}

\section{Dissolution Rates and Blood Concentration of Griseofulvin in Rabbits}

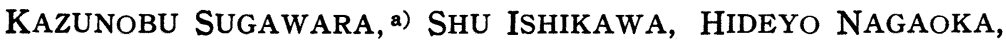 \\ SUEHIRO ITAGAKI, and TEIKO TOYOGUCHI \\ Department of Pharmacy, Yamagata University Hospital*
}

(Received December 16, 1983)

\begin{abstract}
Weight variation test, disintegration test, and dissolution test were made as quality tests for 6 different preparations of griseofulvin. In the dissolution test, water/ethanol $(1: 2, \mathrm{v} / \mathrm{v}) \mathrm{mix}$ ture and double-layer solution of water/n-octanol $(1: 1)$, water/benzene $(1: 1)$ or water/ethyl acetate $(1: 1)$ were used as dissolution mediums. The absorption of griseofulvin was studied by measuring the blood concentration in rabbits.

The dissolution rates and the parameters of the blood levels were different among the preparations. However, the correlation was observed between the results of the dissolution test using the water/n-octanol solution as dissolution medium and the AUC-time curve calculated from the blood concentration in rabbits.
\end{abstract}

Keywords_-griseofulvin; dissolution test; double-layer system; rabbit; blood plasma concentration

グリセオフルビン（以下 GF と略す）は白舞菌治療薬 の経口剂として使用し得る唯一の薬物であり, その有用 性は臨床に欠かせないるのである。しかし難溶性薬物の ため消化管からの吸収が悪く, 吸収量の增大には物理化 学的な製剤因子の工夫改良による溶解速度の元進が望ま れる.1) 難溶性の薬物では消化管内で溶解速度が律速段 階となっているからであり，2) 市販 G F 錠の溶出試験を 行うことは, 各製品間のパイオアベイラビリティの比較 検討に役立つるのと思われる。

難溶性薬物の溶出試験を行うにあたり，従来の方法で は大量の水とそれに伴ら大型容器が必要であった．しか し不便を生じることから溶出溶媒を变えることによっ て，第十改正日本薬局方のパドル法で行うことができる ように検討した. その結果, 溶出液として水とェタノー ルの混液, 並びに水と難溶性の有機溶媒を加えた 2 層液 を用いることにより可能となった。

\footnotetext{
* 山形市蔵王飯田字西の前；Nishinomae, Zao Iida, Yamagata-shi, 990-23 Japan

a) 現: 弘前大学病院薬㓣部
}

本研究は市肘 G F 錠 6 銘柄を用い, 溶出試験による溶 出率を比較するとともに, 家鬼血中濃度を測定し, バィ オアベイラビリティの差を比較検討した。

\section{実 験 の 部}

\section{1. 被験試料}

使用した試料は Table 1 に示した 6 銘柄製品でいず れも GF $125 \mathrm{mg}$ を含有している.

\section{2. 重男偏差試験}

日局十に従い試料各20錠をとり科量した。

\section{3. 崩壊試倹}

日局十に従い崩壊度試験器（富山産業 $\mathrm{T}-2 \mathrm{H}$ 型）を用 いて行った.

\section{4. 溶出試験}

a) 水・エタノール混液による溶出試験

日局十溶出試験法（パドル法）を用いて行った，GF 1 錠を蒸留水 $600 \mathrm{ml}$ の入った試験器に入れ, $100 \mathrm{rpm}$

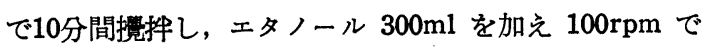
㩭汼し，一定時間毎試料 $2 \mathrm{ml}$ を採取した。な和試料採 取時はメスピペットの先端にファイナルフィルター F 
Table 1. Results of Weight Variation Test and Disintegration Test of Griseofulvin Preparations

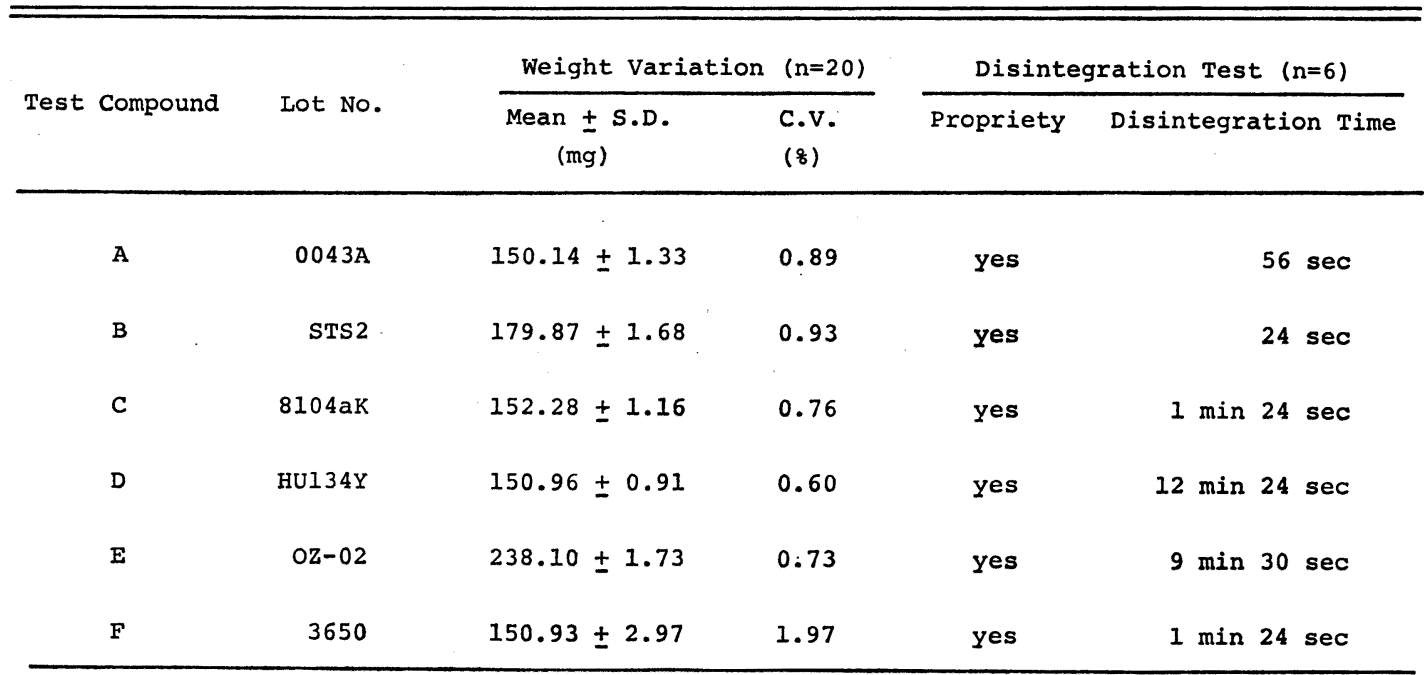

c.v. : coefficient of variation

216 (石川製作所)を取り付けて行った.

試料採取の都度溶出液を同量直ちに補充した，定量は 分光光度計（日立 201 型）にて吸光度波長 $330 \mathrm{~nm}$ で測 定し，各製品について 6 回くり返し行い平均を求めた。

b） 2 層溶媒による溶出試験

日局十溶出試験法に準じて行った．溶出液は蒸留水に n一オクタノール，酢酸エチルまたはベンゼンを加えた 3 種類とした. あらかじめ GF 1 錠を蒸留水 $200 \mathrm{ml}$ の入っ た試験器に入れ，100 rpm で10分間筧拜し，錠剤の崩壊 を行った後，上記有機溶媒 $200 \mathrm{ml}$ を加兄，100 rpm で䨘 找した. 試料採取は溶出液の 2 層分離のため 2 分間静置 した後, 上層の有機溶媒層から a ) と同様にファイナル フィルターを通して行った。 ただし，n一オクタノールに おいては溶媒粘性が高いため，良好な混和状態を得るよ らに 200rpm とした. 定量は a ) 法と同じく分光光度計 にて, 吸光度波長はn-オクタノールの場合 $293 \mathrm{~nm}$, 酢酸 エチルの場合 $290 \mathrm{~nm}$, ベンゼンの場合 $291 \mathrm{~nm}$ で行った.

\section{5. 溶解度試験 .}

水とエタノールの混液および水とn一オクタノールの 2 層液の溶出液に打汀る G F の溶解度を求めた。すなわち 溶出試験器を用いフラスコに溶出液 $100 \mathrm{ml}$ を取り G F 原末を加え $38 \pm 1^{\circ} \mathrm{C}$ で $200 \mathrm{rpm}, 10$ 時間筧拌し, 各溶 出液に打ける溶解度を求めた。

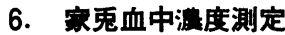

体重 2.5 3.5kg の雄性家鬼を一群 3〜6 羽とし, 薬 物投与24時間前から絶食した。被験試料は粉砕し水を加
え䅗濁し， $50 \mathrm{mg} / \mathrm{kg}$ になるように胃ゾンデにて経口投与 した. 投与 $1,2,3 ， 4,5,6,7,9,24$ 時間後に約 1.5 $\mathrm{ml}$ を耳静脈から採血し，3000 rpm で10分間遠心後，血 清を分離した. GF の定量は Bedford らの改良方法4,5 を用いて行った.すなわち血清 $0.5 \mathrm{ml}$ に $1 \%$ すタノル $1 \mathrm{ml}$ とエチルエーテル $5 \mathrm{ml}$ を加え 90 秒間筧拌後, 2000 rpmで 3 分間遠心し, エーテル層を分離, 蒸発乾固し, $2 \%$ エタール $5 \mathrm{ml}$ を加え, 励起波長 $298 \mathrm{~nm}$, 螢光波 長 $435 \mathrm{~nm}$ で螢光光度計 (日立 204-S 型) にて 測定し た。

\section{实跍菬}

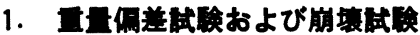

各製品の重量偏差試験および崩壊試験の結果を Table 1 に示した. 重量偏差試験で, 6 製品のうち4製品は 150〜153mg の範囲にあり，1 製品が約 $180 \mathrm{mg}$ と重く， 1 製品は $238 \mathrm{mg}$ であった．各製品とも変動係数は $2 \%$ 以下の範囲であった．崩壊試験においては，製品D， E の崩壊時間が他製品に比べ長かったが, 適否はすべて適 であった.

\section{2. 溶出试験}

a）水・エタノール混液による溶出試験

溶出率曲線を Fig. 1 に示した. 各製品とす水のみで はほとんど溶出せず，エタノールを加えると溶出率が急 速に増加し, 製品 Dが最も早く, 製品Cは溶出率が悪く 70 分後でも約 $60 \%$ の溶出率であった．その他の製品はほ 


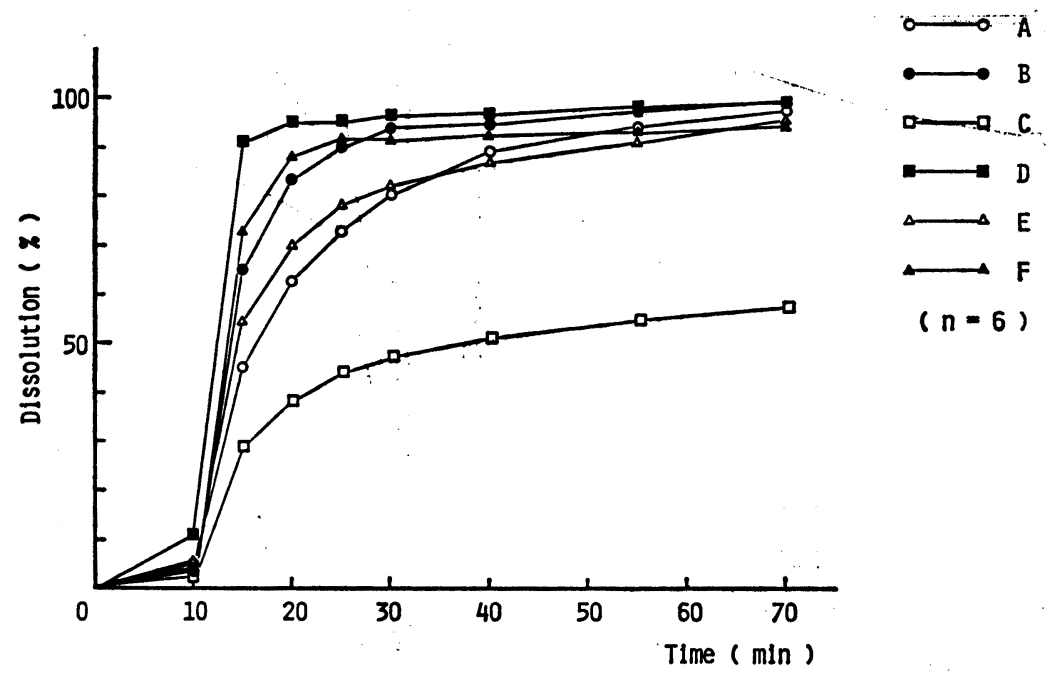

Fig. 1. Dissolution Profiles of Griseofulvin Preparations in Ethanol/Water ( $1: 2)$
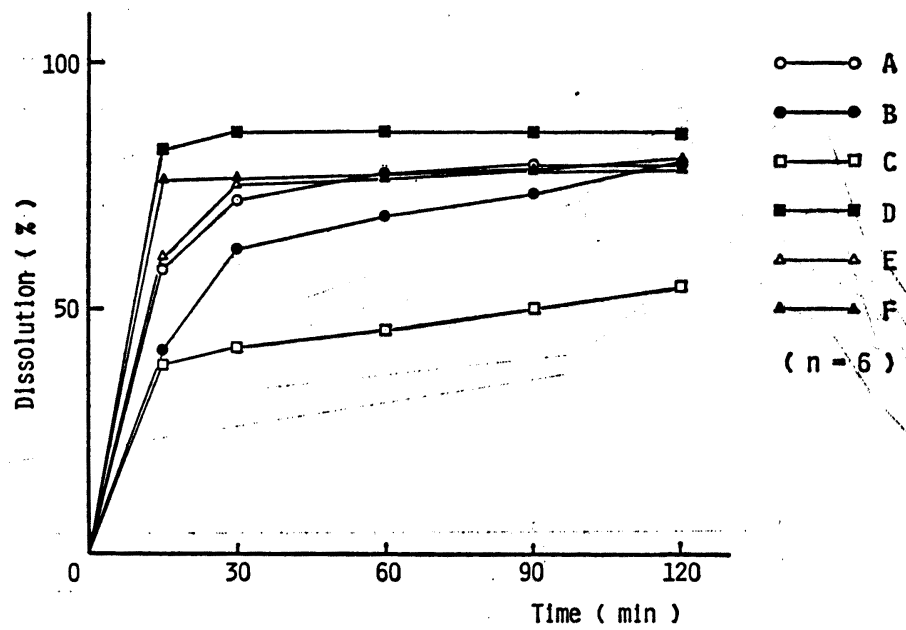

Fig. 2. Dissolution Profiles of Griseofulvin Preparations in $n$-Octanol/Water $(1: 1)$

ぼ同じ溶出曲線を描いた。

b ） 2 層溶媒による溶出試験

各溶媒による溶出率曲線を Fig. 2〜4に示した。水・ n一オクタノール 2 層液では水・エタノール混液と同様に 製品 Dの溶出率が最もよく, 製品 Cが最も悪く, 溶出順 位はB製品を除き同じであった，水・酢酸エチルおよび 水・ベンゼン 2 首液においては製品Cを除きほぼ同じ溶 出率であった．C製品は水・エタノール混液および 3 種 類の 2 層溶出液すべてにおいて溶出速度および溶出率は 最も悪かっだ。

\section{3. 溶解度试験}

水・エタノール混 液での溶解度は $0.11 \mathrm{mg} / \mathrm{ml}$ であ り, 水・n-オクタノールでの溶解度は $1.42 \mathrm{mg} / \mathrm{ml}$ であ った。

\section{4. 家香血中渞度测定}

実験結果を Fig. 5 に, 薬物動態値を Table 2 に示し た。最高血中濃度に達する時間は製品 C, D , Eが 4 〜 5 時間と比較的早いのに対し, 製品 A, B, F は 6 7 時間と差がみられた。最高血中浱度值は製品 B，C， E で $4 \mu \mathrm{g} / \mathrm{ml}$ 以下と低かったのに対し，A，D，Fでは4 $\mu \mathrm{g} / \mathrm{ml}$ 以上であった。半減期はBが14時間と最も長く， 


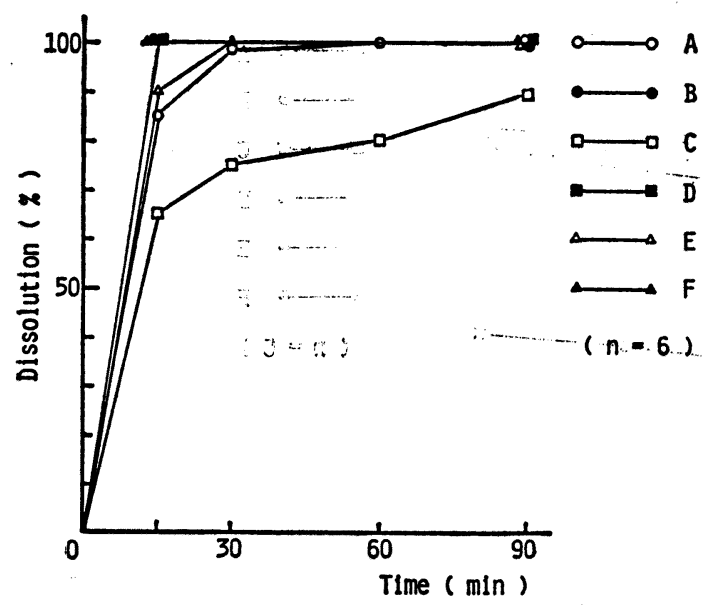

Fig. 3. Dissolution Profiles of -Griseofulvin Preparations in Ethyl Acetate/ Water $(1: 1)$

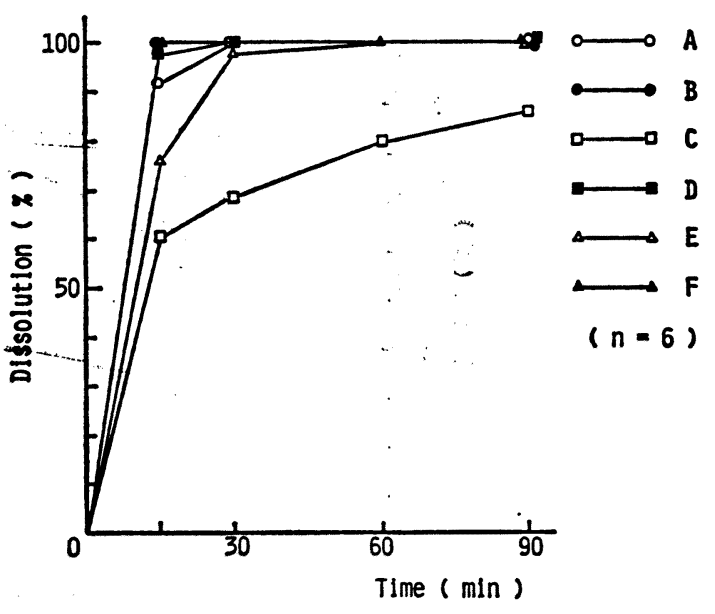

Fig. 4. Dissolution Profiles of Griseofulvin Preparations in Benzene/Water $(1: 1)$

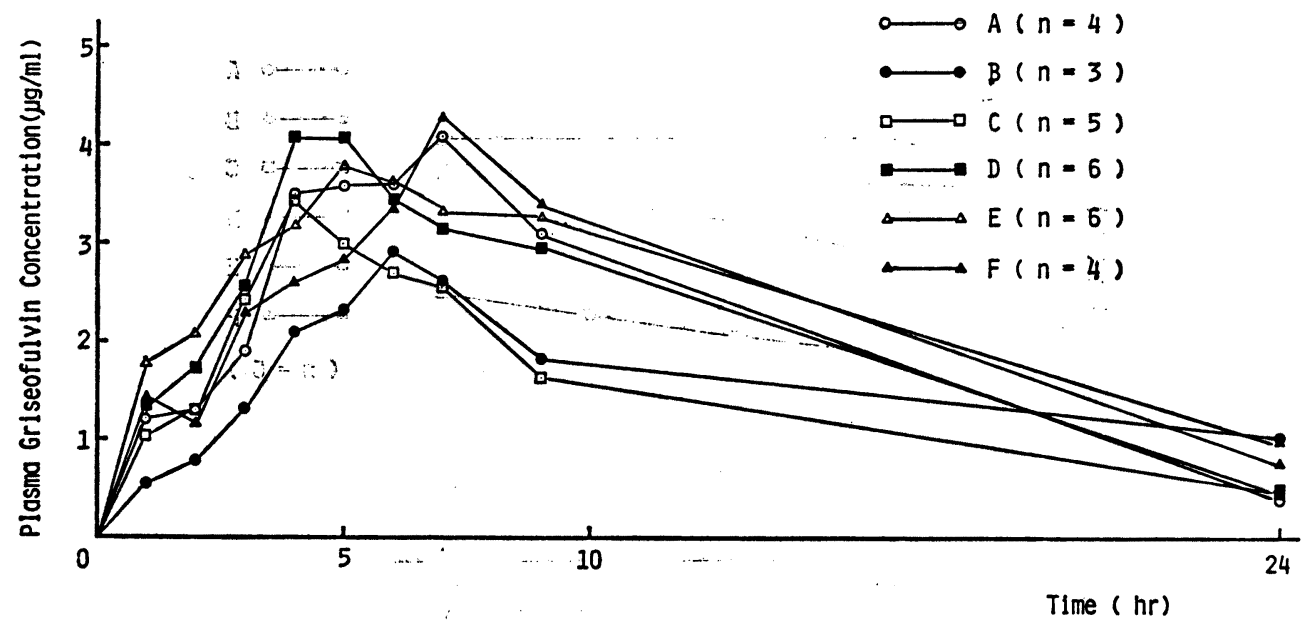

Fig. 5. Changes of Plasma Griseofulvin Concentrations after Oral Administration of Griseofulvin Preparations $(50 \mathrm{mg} / \mathrm{kg}$ ) in Rabbits

次いでD, Eの約10時間であり, 最も短いCで5時間で わった. $A U C_{0 \rightarrow \infty}$ (血中湌度 - 時間曲線下面積) は製品 Fが最す高く，製品Cが最す低く，製品 A， B，D，E はほ注同じ值であった．また，投与後の時間毎の血中瀑 度値を AUC で比較するために, 時間毎の値を求めFig. 6 に示した.

これらの結果から製品 D，Eは吸収が早く持続性があ ク，Cは吸収が早いが持続性がなく，A，Fは吸収が絻 徐であり，Bは吸收が遅く持続性があることがわかっ た.このよらに製品間に拈ける血中動態溔が認められ た. GFとしての吸収後の代謝，排洺には大きな相違は
ないと思われこれら投与後の血中動態の違いは吸収の 差によるものと考えられる。

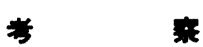

市肘G F 錠 6 製品について，溶出試験および家鬼血中 浱度測定を行った．崩壊試験と溶出試験との結果を比較 した场合，崩壞の遲い製品Dが溶出举轩が早くあらわれ ていたが，溶出挙動の悪い製品 Cは平均的な崩壞時間を とっていた. このよらに崩壤試験結果と溶出試検結果と の間には相関性を見ることができなかった。

溶出液による溶解度と容出性を比较した場合，水・n- 


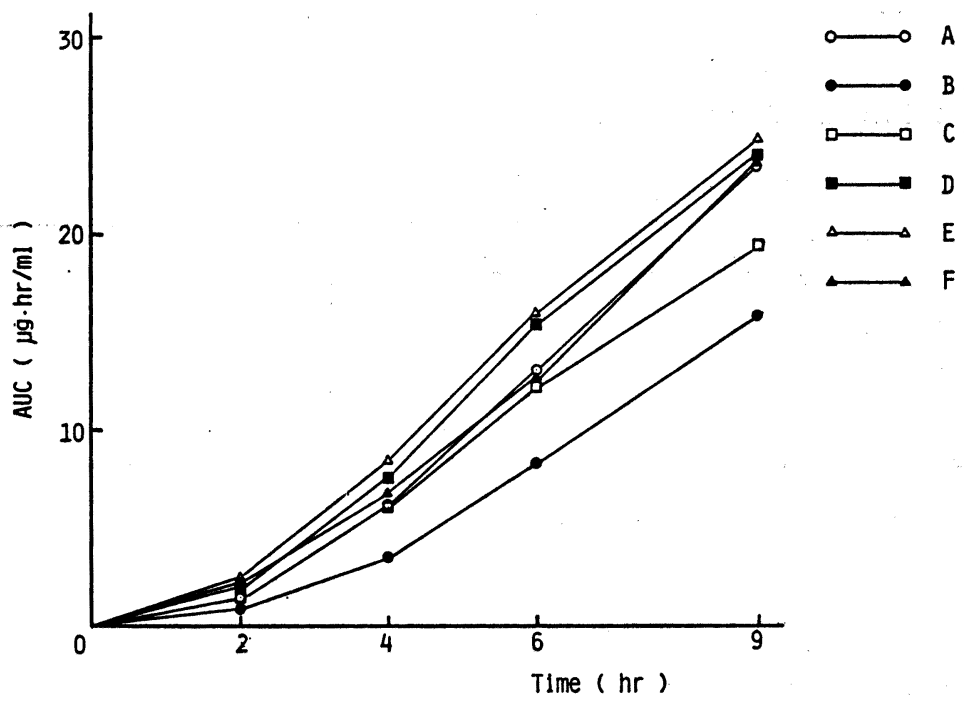

Fig. 6. Time-AUC Curve of Griseofulvin Preparations

Table 2. Pharmacokinetic Parameters of Griseofulvin in Rabbits

\begin{tabular}{cccccc}
\hline \hline Test Compound & $\mathrm{n}$ & $\begin{array}{c}\left.\mathrm{C}_{\max } \mathrm{a}\right) \\
(\mu \mathrm{g} / \mathrm{ml})\end{array}$ & $\begin{array}{c}\left.\mathrm{T}_{\max } \mathrm{b}\right) \\
(\mathrm{hr})\end{array}$ & $\begin{array}{c}\left.\mathrm{T}_{1 / 2} \mathrm{c}\right) \\
(\mathrm{hr})\end{array}$ & $\begin{array}{c}\left.\mathrm{AUC} \mathrm{C}_{0} \mathrm{~d}\right) \\
(\mu \mathrm{gg} \cdot \mathrm{hr} / \mathrm{ml})\end{array}$ \\
\hline $\mathrm{A}$ & 4 & 4.2 & 7 & 7.7 & 55.3 \\
B & 3 & 2.9 & 6 & 14.0 & 62.9 \\
C & 5 & 3.4 & 4 & 5.0 & 36.6 \\
$\mathrm{D}$ & 6 & 4.1 & 4 & 9.7 & 57.4 \\
$\mathrm{E}$ & 6 & 3.8 & 5 & 10.3 & 67.3 \\
F & 4 & 4.3 & 7 & 8.3 & 83.5 \\
\hline
\end{tabular}
a) Peak plasma concentration
b) Time reached to peak plasma level
c) Biological half-life of elimination phase
d) Area under plasma concentration curve at $0-\infty \mathrm{hrs}$

オクタノール混液に比べ溶解度の低い水・エタノール混 液の方が溶出挙動および溶出率がよくあらわれていたこ とは，溶出溶媒である水・エタノールの完全混和と水・ nーオクタノールでの不完全混和の迺い,および製品賦形 凧の溶媒中での溶解度差が錠郕の崩壊分散性に与える影 䈉によるるのと考えられる。

次に各溶出液による溶出試験と家鬼血中䈨度を比較し た場合，求めた各バラメーター数值から直接比較するこ
とは困難であったため，AUC一時間曲線を取った．溶出 曲線勾配より見られる溶出挙動を消化管からの吸収速度 として、また溶出曲線がプラトーに達したときを最大溶 出率として評価した場合，溶出挙動および溶出率の悪い 製品C飞おいて $\mathrm{AUC}_{0 \rightarrow 9}$ 值と $\mathrm{AUC}_{0 \rightarrow \infty}$ 值が低かった ため, 溶出試験, 血中濃度両者に一致をみることができ た. また水・エタノール混液と水・nーオクタノール2 層 液による溶出試験で，溶出順位の違いがあった製品 B に 
A

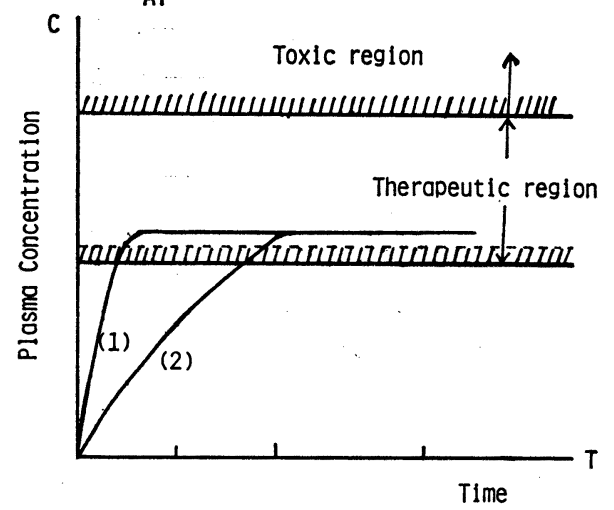

B.

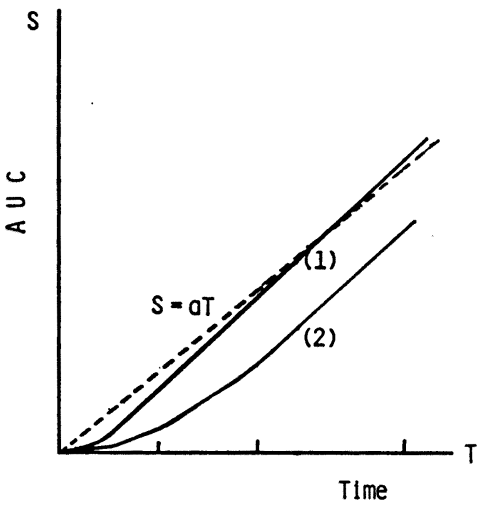

Fig. 7. Theoretical Time-Concentration Curve (A) and Time-AUC Curve (B)

おいて, $\mathrm{AUC}_{0 \rightarrow 9}$ 值が低いにもかかわらず, $\mathrm{AUC}_{0 \rightarrow \infty}$ 值が他の製品と同様にほぼ平均的な值を示した。このこ とは AUC一時間曲線の推移とn一オクタノール層での溶 出曲線の推移が類似していることが関与しているものと 考学られる.これから判断すると，今後の難溶性薬物の 溶出試験を行う際にnーオクタノール層を使用することも

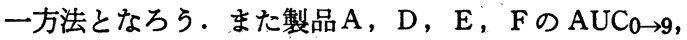
$\mathrm{AUC}_{0 \rightarrow \infty}$ 值をみた場合も结注同じ值であり，各溶出試 験とほぼ一致するものと思われる.

ところでG F が標的組織である角質表皮層へ到達する までには相当の時間を要し，6) かつ白舞菌に対する組織 内有効濃度 ${ }^{5,7)}$ とその維持時間が必要となることを考慮 すれば，G F 錠が生体側により効果的なバイオフベイラ ビリティを発揮するには，安全域内での有効血中濃度に より早く達し，その濃度をより長く維持できる製剤であ ることが望まれる。これをFig. 7 A で示すと血中濃度曲 線の立ち上りが速やかに有効血中濃度に達し，そのまま 長時間維持できる状態（值線(1)）が理想的であり，その AUC を AUC一時間曲線に置き換えると Fig. 7 B の㨁 線(1)になる. 薬物の有効血中濃度が定まっていれば, 推 移時間による AUC 值の増加量の比が一定(a)となること から直線 $\mathrm{S}=\mathrm{aT}$ として描かれる. 消化管からの吸収が 緩徐で有効血中濃度に達する時間が遅い場合, AUC一時 間関係の直線(2)は血中濃度に達した時間から勾配 a の直 線(1)とパラレルな直線を描くことになる。

今回の実験の上うにG F の有効血中浱度が未知で, 実 際に忹角質内有効濃度を必要とする場合, AUC一時間曲 線から製剤倸研を仮定すると次の 2 点が必要条件になる 3. 第 1 点はG F が難吸収性であることから，ある時間 内飞より高い AUC 值を得るといら吸収速度の問題であ
り，第 2 点はその AUC の増加曲線がより直線的である

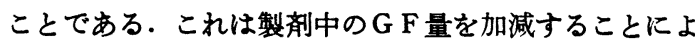
って血中濃度を有効濃度にコントロールしやすくできる からである。

以上の点から $\mathrm{AUC}_{0 \rightarrow 9}$ 值をみると，製品 $\mathrm{A}, \mathrm{D}, \mathrm{E}$ ， Fがほ注同じであり，Fig. 6 亿拉いて原点から $\mathrm{AUC}_{0 \rightarrow 9}$ 值付近飞直線を引いた時, 近似曲線をみせた製品 D, E がすぐれていると考えられる．これは他の製品に比べて 血中濃度の立ち上り，すなわち吸収が早かった結果と考 えられる。

今回は家鬼を用いた実験であるが，臨床においても製 凮改良による吸収量の增大が治慜効果を上げたとの報告 があり，8,9) 今後さらに理想的な AUC一時間曲線を満た し，一層治慗効果を高める製品が作られることを期待し たい。

\section{文献}

1) R. Atkinson, C. Bedford, K.T. Child, E.G. Tomich: Nature, 193, 588 (1962).

2) B. Katchen, S. Symchowicz: J. Pharm. Sci., 56, 1108 (1967).

3) N. Khalafalla: Pharmazie, 35, 555 (1980).

4) C. Bedford, K. J. Child, E.G. Tomich : Nature, 184, 364 (1959):

5）鴫崎 匡: 真菌誌, 6, 115 (1965).

6）高野正彦，木村修三，石浜 毅：薬局， 32，141 (1981).

7) 伊藤文利はか：最新医学，18，2914 (1963).

8）三浦喛晶, 嶋崎匡, 岩田美恵子: 皮席科紀 要, 58, 158 (1963).

9) M. Kraml, J. Bubuc, R. Guadry : Antibiot. Chemotherapy, 12, 232 (1962). 